\title{
RADIOCARBON ANOMALIES OBSERVED FOR PLANTS GROWING IN ICELANDIC GEOTHERMAL WATERS
}

\author{
ÁRNÝ E. SVEINBJÖRNSDÓTTIR', JAN HEINEMEIER ${ }^{2}$, NIELS RUD ${ }^{2}$ and \\ SIGFÚS J. JOHNSEN ${ }^{1}$
}

ABSTRACT. We have studied plant remains in thick beds of lacustrine sediments in the upper part of the Markarfljót
drainage area in southern Iceland. We collected small samples of plant species from the same horizon and ${ }^{14} \mathrm{C}$ dated them
at the Aarhus AMS Dating Laboratory. Terrestrial plants yielded an age of $9 \mathrm{ka} \mathrm{BP}$, whereas aquatic moss (Fontinalis
antipyretica Hedw.) yielded the surprisingly old ${ }^{14} \mathrm{C}$ age of $16 \mathrm{ka} \mathrm{BP}$. We believe the age of the terrestrial plants reflects
the true age of the sediment. The anomalously old ${ }^{14} \mathrm{C}$ age of the aquatic moss may be an effect of geothermal water on
the moss, as the area is known to be geothermally active today. Modern aquatic moss growing in geothermal water showed
a similar ${ }^{14} \mathrm{C}$ anomaly, with measured ages ranging from 6 to $8 \mathrm{ka} \mathrm{BP}$, which may be explained by the equally old ages
measured for the corresponding water samples. The ${ }^{14} \mathrm{C}$ content of geothermal springs and neighboring rivers in the area
ranges from 9 to $50 \mathrm{pMC}$, equivalent to an apparent age of $20-5.5 \mathrm{ka} \mathrm{BP}$.

\section{INTRODUCTION}

Scientists have noted that ${ }^{14} \mathrm{C}$ ages can be overestimated in organisms that have lived in the vicinity of volcanoes (Saupé et al. 1980; Bruns et al. 1980; Chatters, Crosby \& Engstrand 1969). This has been explained by increased concentration of volcanic $\mathrm{CO}_{2}$ in the atmosphere, which lowers the ${ }^{14} \mathrm{C}$ activity of atmospheric $\mathrm{CO}_{2}$. Saupe et al. (1980) concluded that ${ }^{14} \mathrm{C}$ activity is too low in plants grown in the vicinity of volcanic emanations because of natural ${ }^{14} \mathrm{C}$ dilution, which yields anomalously old ages. Plants living close to a declining volcano in Tuscany, Italy were depleted in ${ }^{14} \mathrm{C}$, giving an erroneous age (Saupé et al. 1980). Bruns et al. (1980) concluded, after studies on living plants in the Eifel area, West Germany and Thera, Greece, that mixing of "dead" $\mathrm{CO}_{2}$ may lead to false ages, in archaeological or geological samples, of up to $16 \mathrm{ka}$ in samples from the vicinity of $\mathrm{CO}_{2}$ emanations. A similar effect, the so-called hard-water effect, is seen for aquatic plants growing in lakes with an inflow of calcareous groundwater (Mook \& Van de Plassche 1986).

Iceland, which is situated on the boundary between the American and European plates, is volcanically very active. The boundary, generally called the Neovolcanic Zone, is characterized by active volcanism, seismicity and graben structure. According to Sæmundsson (1979), 24 volcanic systems have been active in postglacial time, producing about $400-500 \mathrm{~km}^{3}$ of lava. Geothermal areas are frequently associated with these volcanic complexes. The thermal areas are conventionally divided into two groups according to their base temperatures, generally referred to as the high and low temperature areas (Bödvarsson 1961). The low-temperature areas are confined to areas outside the Neovolcanic zones, and are characterized by hot water springs and a relatively low degree of thermal alteration. The high-temperature areas are within the active volcanic zones. Their surface activity is characterized by natural steam vents, boiling mudpools and highly altered ground. At present, there are 22 certain and 3 potential high-temperature areas in Iceland (Fridleifsson 1979). These areas are always associated with volcano-tectonic features, such as fissure swarms and/or central volcanoes. Despite the volcanic activity, ${ }^{14} \mathrm{C}$ age dating of plant remains and mollusks has been very successful in Iceland. Volcanic activity has not been known to have caused any major errors in ${ }^{14} \mathrm{C}$ results of geological samples. Thus, after extensive data collection, Olsson (personal communication, 1991) suggests a general atmospheric ${ }^{14} \mathrm{C}$ depletion in Iceland corresponding to

${ }^{1}$ Science Institute, University of Iceland, IS107 Reykjavík, Iceland

${ }^{2}$ Institute of Physics, University of Aarhus, DK-8000, Aarhus C, Denmark 


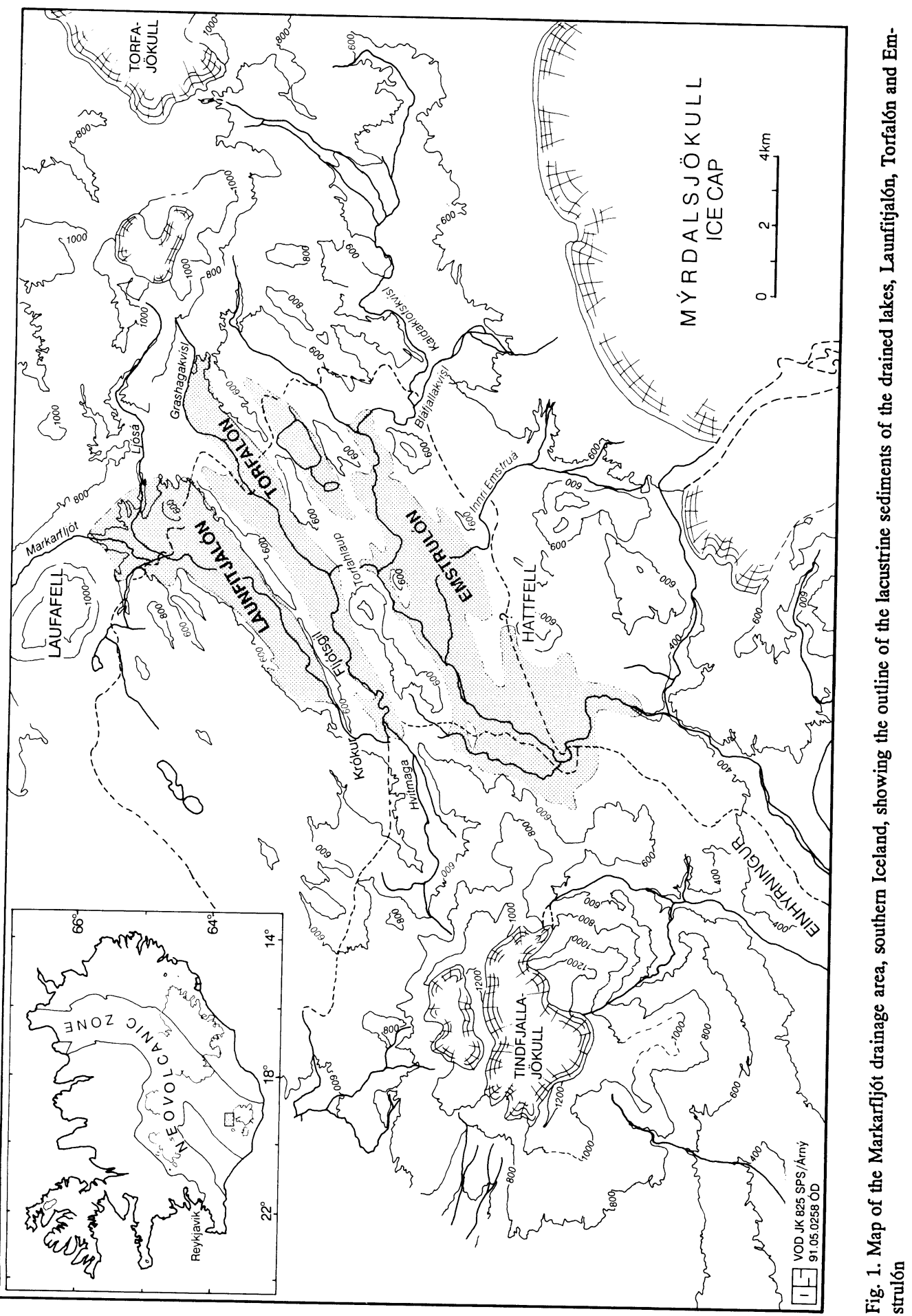


age anomalies of no more than 30-50 yr. Hard-water effect is unlikely in Iceland, as Icelandic bedrock contains no calcareous rock.

In this study, we report, for the first time, anomalously old ${ }^{14} \mathrm{C}$ ages of Icelandic geological samples that can be explained by volcanic activity. In the Markarfljót drainage area, southern Iceland, we observed an age anomaly of $8 \mathrm{ka}$, and data from our subsequent study of modern aquatic mosses from geothermal environment suggest that this anomaly may be due to low ${ }^{14} \mathrm{C}$ levels in geothermal water.

\section{THE MARKARFLJÓT DRAINAGE AREA}

\section{Geological Setting}

The Markarfljót drainage area lies just northwest of the Mýrdalsjökull ice cap (Fig. 1). The area is characterized by hyaloclastite ridges formed in subglacial fissure eruptions, and by thick lacustrine sediments in depressions between the ridges. One of the most active geothermal areas in Iceland is located at the northern border of the Markarfljót drainage area, which is thought to have been the stronghold for glaciation during the last glaciation. Einarsson (1988) believes that the glacier was thickest here, and the main ice divide cut through the area. Accordingly, Weichselian ice disappeared from this area only at the very latest stage of the last glaciation. With improving climate, the glaciers disappeared gradually, some 10-8 ka ago, accompanied by a huge amount of meltwater and formation of extensive glacial lakes. At least three big lakes developed in the upper part of the Markarfljót drainage area (Kaldal \& Vilmundardóttir 1989). The lakes were gradually filled with material transported by meltwater streams, leaving thick beds of lacustrine sediments. After subsequent draining of the lakes, the rivers cut deep channels and furrows into the lake beds, where the deepest channel exposes about $25 \mathrm{~m}$ of lacustrine sediments. The sediments consist of laminated silt and sand, overlain by a few meters of gravel, that, in some places, is overlain by soil rich in tephra (Fig. 2). Identification of the tephra layers dates the oldest lacustrine sediments to the beginning of the Preboreal (Kaldal \& Vilmundardóttir 1989).

\section{Radiocarbon Samples}

Plant remains have been observed within two of the sediment basins, viz., Launfitjalón and Torfalón (Fig. 1). The fossil material is found in thin, sandy layers, sandwiched between layers of laminated silt. All the plants are thought to have been transported by glacial meltwater streams and redeposited in the glacial lakes. Figure 2 shows the sediment profiles and sample sites. The amount of available fossil material is minute, but with the AMS Icelandic-Danish dating collaboration, described below, we have been able to conduct a systematic ${ }^{14} \mathrm{C}$ study of these plant remains.

After standard physical and chemical purification of the samples, the carbon is transformed to $\mathrm{CO}_{2}$, which is partly used for $\delta^{13} \mathrm{C}$ measurements at the Science Institute, Reykjavík, and partly converted to graphite for AMS ${ }^{14} \mathrm{C}$ measurements in Aarhus, Denmark. The graphitization system (in Reykjavík) is very similar to that of Vogel et al. (1984). The AMS system in Aarhus has been described in some detail previously (Andersen et al. 1989). The present accuracy in ${ }^{14} \mathrm{C}$ measurements is limited only by ion-counting statistics (typically $\pm 1 \%$ ), since possible systematic errors have been shown to be less than a few per mil in a large test program dating 65 samples of known ages. The ${ }^{13} \mathrm{C}$ values are also measured with the Aarhus AMS system, and they agree within a few per mil with the more precise values determined by conventional mass spectrometry in Reykjavík. All ${ }^{14} \mathrm{C}$ concentrations and calculated ages presented here are corrected for fractionation (Andersen et al. 1989). 


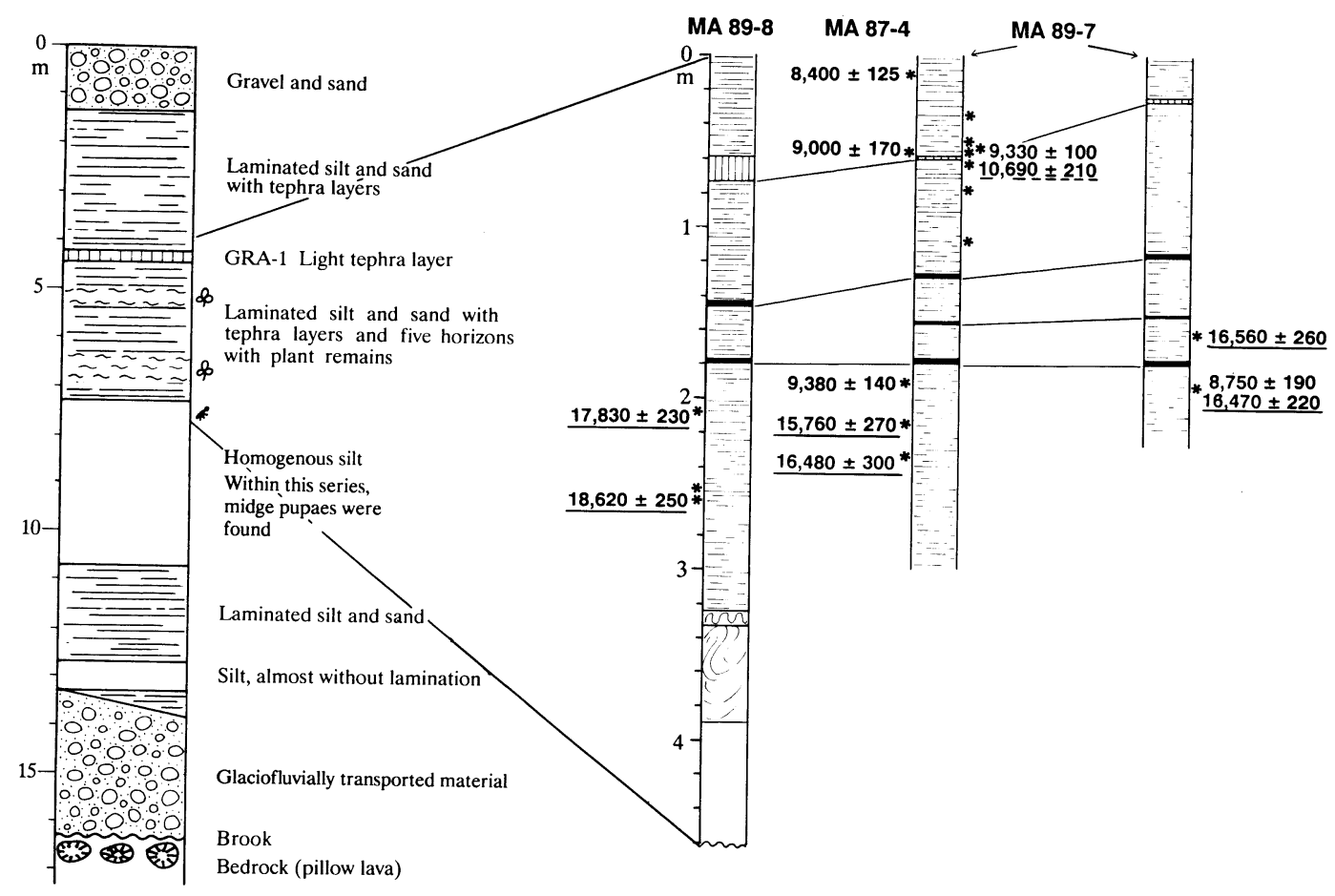

Fig. 2. Lacustrine sediment profiles from the drained lake Torfalón. Plant remains are indicated by ${ }^{*}$ and ${ }^{14} \mathrm{C}$ dates are given in conventional ${ }^{14} \mathrm{C}$ years BP. Dates obtained for the aquatic moss are underlined and a mixed terrestrial/aquatic sample is indicated by a dashed line.

\section{Results}

Table 1 gives the results of the ${ }^{14} \mathrm{C}$ and $\delta^{13} \mathrm{C}$ measurements. Plant remains from ten plant horizons, spanning a sedimentation depth of $2 \mathrm{~m}$, yielded ages generally increasing with depth from $c a .9$ to $18 \mathrm{ka} \mathrm{BP}$, as shown in Figure 2. The middle profile (MA-87-4) contains the first set of data originally collected (Kaldal \& Vilmundardóttir 1989) and measured. It shows a large age interval from 9.4 to $15.5 \mathrm{ka} \mathrm{BP}$, occurring within only $20 \mathrm{~cm}$, where no indication of hiatus or glaciation can be detected in the sediments. Also, the old maximum age (18 ka BP) is surprising, in itself, as it coincides with the last glacial maximum.

The samples below the above-mentioned interval consist exclusively of a black, stringy type of aquatic moss (Fontinalis antipyretica Hedw.), whereas the samples above the interval are mostly terrestrial plants (see Table 1), suggesting a systematic apparent age difference between the two types of plants. As seen in Table 1, they have $\delta^{13} \mathrm{C}$ values, $-30 \%$ and $-25 \%$, respectively. The age difference was confirmed by a subsequent, successful search for a plant horizon containing both types of plants (profile MA-98-7, Fig. 2). The small-sample capability of AMS allowed separate dating of terrestrial and aquatic plants, yielding an age of $8750 \pm 190 \mathrm{BP}$ (AAR-110) and 16,470 \pm 220 BP (AAR-109), respectively (Table 1).

The same type of aquatic moss found in the profiles grows today in Iceland in rivers and occasionally in lakes up to $500 \mathrm{~m}$ altitude. The large apparent age difference of $8 \mathrm{ka}$ in samples supposed to date the same sediment layer is a challenge to the reliability of our dates. The age of the terrestrial plants may reflect the true age of the sediments. This would agree with former studies of postglacial time in Iceland. The higher ages (>15 ka), on the other hand, are least accep- 
TABLE $1 .{ }^{14} \mathrm{C}$ and $\delta^{13} \mathrm{C}$ values for plant remains from lacustrine sediment profiles in the Markarfljót drainage area, southern Iceland

\begin{tabular}{|c|c|c|c|c|}
\hline AAR-no. & Profile & Plant type & $\begin{array}{c}\text { Conventional }{ }^{14} \mathrm{C} \text { age } \\
\text { (BP) }\end{array}$ & $\begin{array}{c}\delta^{13} \mathrm{C} \\
(\% \circ \mathrm{PDB})\end{array}$ \\
\hline \multicolumn{5}{|c|}{ A. Launfitjalón } \\
\hline 103 & $85-3$ & Aquatic & $14,790 \pm 250$ & \\
\hline 104 & $87-8 a$ & Aquatic & $15,700 \pm 330$ & \\
\hline \multicolumn{5}{|c|}{ B. Torfalón } \\
\hline 195 & $87-4-0$ & Terrestrial & $8400 \pm 125$ & \\
\hline 099 & $87-4-1$ & Terrestrial & $9000 \pm 170$ & \\
\hline 100 & $87-4-2$ & Terrestrial & $9380 \pm 140$ & \\
\hline 101 & $87-4-3$ & Aquatic & $15,760 \pm 270$ & \\
\hline 102 & $87-4-4$ & Aquatic & $16,480 \pm 300$ & \\
\hline 196 & $87-4-4$ & Aquatic & $18,840 \pm 220$ & \\
\hline 111 & $87-7 \mathrm{C}$ & Terrestrial & $9330 \pm 100$ & -25.4 \\
\hline 105 & $89-7 \mathrm{E}$ & Mixed & $10,690 \pm 210$ & -25.9 \\
\hline 108 & $89-7 \mathrm{H}$ & Aquatic & $16,560 \pm 260$ & -30.0 \\
\hline 110 & 89-7 Ia & Terrestrial & $8750 \pm 190$ & \\
\hline 109 & $89-7 \mathrm{Ib}$ & Aquatic & $16,470 \pm 220$ & -29.1 \\
\hline 107 & $89-8 \mathrm{~A}$ & Aquatic & $17,830 \pm 230$ & -29.8 \\
\hline 106 & $89-8 \mathrm{~B}$ & Aquatic & $18,620 \pm 250$ & -30.7 \\
\hline
\end{tabular}

The following species were identified in the terrestrial plant samples:

Mosses:

Drepanocladus aduncus (Hedw.) Warnst.

Philonotis fontana (Hedw.) Brid.

Pohlia filum (Schimp.) Maort.

Dichodontium pellucidum (Hedw.) Schimp.

Hygrohypnum ochraceum (Wils.) Loeske

Pohlia wahlenbergii (Web. et Mohr) Andr.

Grasses:

Alopecurus aequalis Sobol

Catabrosa aquatica (L.) P. Beauv.

Salix herbacea $\mathrm{L}$.

table, since they correspond to the last glacial maximum, and might reflect an effect of a ${ }^{14} \mathrm{C}$ depletion of the water the plants grew in. In order to test this hypothesis and to check whether the younger age for the terrestrial plants does reliably date the sediments, we have studied modern moss in the geothermal environments of the Hveragerði area.

\section{MODERN MOSS IN A GEOTHERMAL ENVIRONMENT}

Hveragerði is an active geothermal area some $40 \mathrm{~km}$ east of Reykjavík, Iceland. The area lies within the volcanically active zone of southern Iceland, and is connected to the central volcano, Hengill. Natural boiling springs are common here. We collected several samples of terrestrial moss, aquatic moss and the water in which they had grown, from one of these springs. For comparison, we also collected a moss sample from the Hólmsá River, which has no connection to geothermal or volcanic activity. 


\section{Radiocarbon Samples}

Prior to ${ }^{14} \mathrm{C}$ analyses, the moss samples were pretreated as described above. The water samples were collected into 1-liter bottles. A 1-M filtered solution of $\mathrm{BaCl}_{2}$ and $\mathrm{NaOH}$ was added to the samples to precipitate the dissolved inorganic carbon (DIC) as $\mathrm{BaCO}_{3}$. The precipitate was treated with phosphoric acid $\left(\mathrm{H}_{3} \mathrm{PO}_{4}\right)$ on the AMS preparation line to evolve $\mathrm{CO}_{2}$. The total $\mathrm{CO}_{2}$ given in Table 2 was calculated from the amount of precipitate and the relative yield of $\mathrm{CO}_{2}$. Part of the yield may be due to particulate carbonate in the samples, which were not filtered prior to treatment, as these are expected to have the same ${ }^{14} \mathrm{C}$ content as the DIC.

TABLE 2. Apparent ${ }^{14} \mathrm{C}$ ages and $\delta^{13} \mathrm{C}$ values for plant and water samples from the Hveragerði geothermal area and from Hólmsá, Iceland with sample sites marked in order of increasing distance from the source of a hot spring (Fig. 3)

\begin{tabular}{|c|c|c|c|c|c|c|c|c|}
\hline AAR-no. & Site & $\begin{array}{l}\text { Sample } \\
\text { type }\end{array}$ & Environment & $\begin{array}{l}\text { Temp. } \\
\left({ }^{\circ} \mathrm{C}\right)\end{array}$ & $\begin{array}{l}\text { Conv. }{ }^{14} \mathrm{C} \\
\text { age }(\mathrm{yr} \mathrm{BP})\end{array}$ & $\begin{array}{c}{ }^{14} \mathrm{C} \text { value } \\
\text { (pMC) }\end{array}$ & $\begin{array}{c}\delta^{13} \mathrm{C} \\
(\% \circ \mathrm{PDB})\end{array}$ & $\begin{array}{c}\Sigma \mathrm{CO}_{2} \\
\left.(\mathrm{mg} \mathrm{liter})^{-1}\right)\end{array}$ \\
\hline \multicolumn{9}{|c|}{ 1A. Hveragerði, water and aquatic plants } \\
\hline 169 & 1 & Water & Hot spring & 60 & $20,200 \pm 230$ & $8.1 \pm 0.2$ & -1.9 & 122 \\
\hline 170 & 2 & Water & Hot spring & 40 & $17,290 \pm 260$ & $11.6 \pm 0.4$ & -1.6 & 216 \\
\hline 171 & 3 & Water & Mixed stream & 21 & $9940 \pm 430$ & $29.0 \pm 1.6$ & -0.3 & 61 \\
\hline 180 & 3 & Aqu. plant & Mixed stream & 21 & $7960 \pm 130$ & $37.1 \pm 0.6$ & -30.6 & \\
\hline 161 & 3 & Aqu. plant & Mixed stream & 21 & $8330 \pm 170$ & $35.5 \pm 0.8$ & -30.4 & 65 \\
\hline 662 & 4 & Water & Mixed stream & 21 & $9830 \pm 200$ & $31.1 \pm 0.8$ & & \\
\hline 192 & 4 & Aqu. plant & Mixed stream & 21 & $8260 \pm 180$ & $35.8 \pm 0.8$ & -29.5 & \\
\hline 159 & 5 & Aqu. plant & Slow stream & 30 & $6320 \pm 90$ & $45.5 \pm 0.5$ & -30.5 & 40 \\
\hline 172 & 6 & Water & Cold river & 7 & $5800 \pm 110$ & $48.6 \pm 0.7$ & 0.7 & \\
\hline \multicolumn{9}{|c|}{ 1B. Hveragerði, terrestrial plants } \\
\hline 179 & 1 & Terr. plant & Hot spring & & Modern & $114.3 \pm 1.3$ & -24.5 & \\
\hline 694 & 1 & Terr. plant & Hot spring & & Modern & $115.8 \pm 1.8$ & -28.2 & \\
\hline 693 & 2 & Terr. plant & Mixed stream & & Modern & $116.1 \pm 0.8$ & -26.1 & \\
\hline 692 & 5 & Terr. plant & Cold river & & Modern & $113.8 \pm 0.9$ & -26.8 & \\
\hline \multicolumn{9}{|c|}{ 2. Hólmsá, river far from geothermal activity } \\
\hline 162 & & Aqu. plant & & & Modern & $109.7 \pm 1.1$ & -35.6 & \\
\hline
\end{tabular}

Our standard background samples, graphitized directly from $\mathrm{CO}_{2}$ from Icelandic double spar ( $c a$. $15 \mathrm{Ma}$ ), yielded ${ }^{14} \mathrm{C}$ levels equivalent to $42 \mathrm{ka} \mathrm{BP}$, whereas demineralized water samples prepared by absorption of $\mathrm{CO}_{2}$ from Icelandic double spar yielded levels corresponding to $28 \mathrm{ka} \mathrm{BP}$. The water samples prepared in this way give an upper limit for contamination with modern $\mathrm{CO}_{2}$, as they were exposed to air for longer periods after alkalinization than the normal water samples. As the exact background value is not known and is of no consequence to our conclusions, we chose to use the $42 \mathrm{ka}$ BP level of our standard blanks for background correction.

\section{Results}

Figure 3 shows a schematic map of the Hveragerði study area, together with sampling sites and corresponding ${ }^{14} \mathrm{C}$ dates for water and aquatic moss samples. The sampling strategy was to collect terrestrial plants, aquatic moss (Fontinalis antipyretica Hedw.) and water from a profile starting at a hot spring and following its outflow into larger and colder rivers (Sites 1 to 6). We found no Fontinalis antipyretica Hedw. growing in the warmest stream $\left(>40^{\circ} \mathrm{C}\right)$, so that samples were available only from medium temperatures. The full results of our measurements are shown in Table 2. The data demonstrate that modern aquatic moss in Hveragerði gives anomalously old ages from 6 to $8 \mathrm{ka} \mathrm{BP}$. The measured ${ }^{14} \mathrm{C}$ ages of the corresponding waters are similar, although slightly 
higher. The moss result from Hólmsá, with no geothermal activity, concurs with normal modern ${ }^{14} \mathrm{C}$ values. This is also the case for terrestrial plants sampled in Hveragerði, where we saw no significant variation with distance from the hot spring (Table 2). Even samples taken within $3 \mathrm{~m}$ of the source (AAR-179 and -694, Site 1, Fig. 3) show no sign of ${ }^{14} \mathrm{C}$ depletion, in spite of strong vapor and gas emanation from the source. In the Hveragerdi area, the ages of the water samples range from a maximum of $20 \mathrm{ka} \mathrm{BP}$ at the source of the hot spring, dropping to $6 \mathrm{ka} \mathrm{BP}$ as the distance from the source increases. The drop is due to exchange with atmospheric $\mathrm{CO}_{2}$ and dilution with nongeothermal surface water. In the larger cold river (Site 6) (Fig. 3), the apparent age (5.8 $\mathrm{ka}$ BP) is still surprisingly old, and is probably due to the high DIC content of the influent geothermal streams.

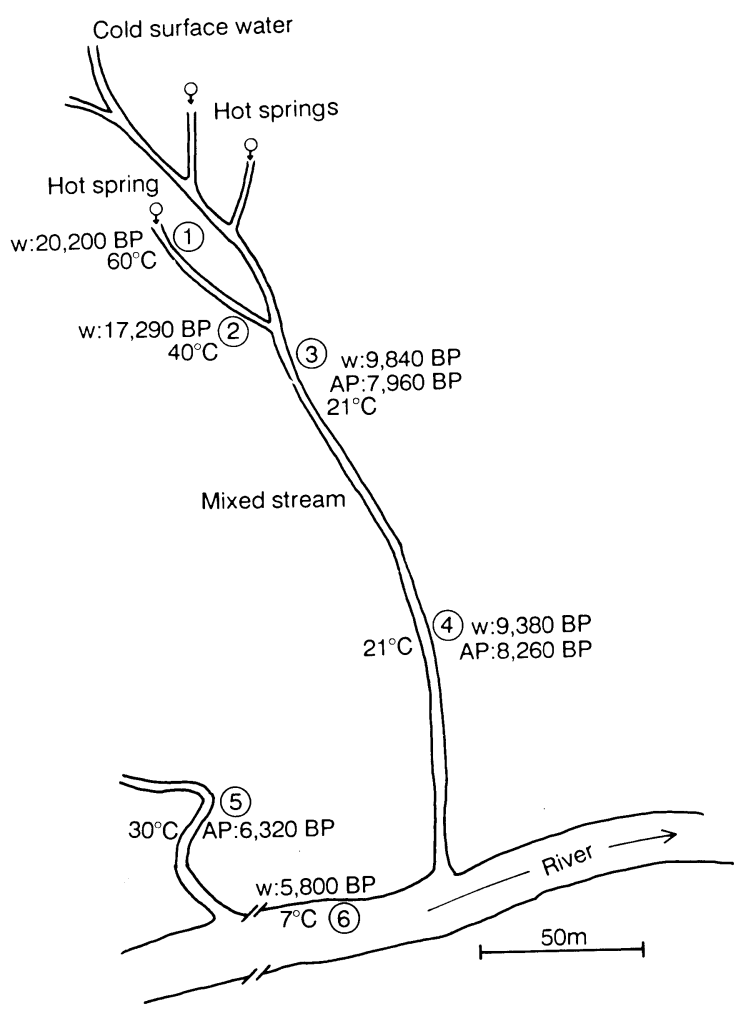

Fig. 3. Schematic diagram of the Hveragerði geothermal study area. Sample sites from 1 to 6 are indicated and the ${ }^{14} \mathrm{C}$ results are given for water samples $(\mathrm{w})$ and modern aquatic plants (AP). Water temperatures are also shown.

\section{CONCLUSION}

We have demonstrated substantial ${ }^{14} \mathrm{C}$ age anomalies for aquatic plants growing in geothermal waters. Their exchange with atmospheric $\mathrm{CO}_{2}$ seems to be sufficiently slow for large areas to be affected. However, neighboring terrestrial plants are unaffected by geothermal activity. This provides a plausible explanation for the difference between ${ }^{14} \mathrm{C}$ ages observed for aquatic and terrestrial plant remains in Markarfljót lacustrine sediments. Aquatic mosses may have become ${ }^{14} \mathrm{C}$ depleted by growing in geothermal water. This is also supported by the observation that both the Markarfljót and Hveragerði aquatic mosses all have $\delta^{13} \mathrm{C}$ values of $-30 \%$, whereas the same type of moss from the non-geothermal Hólmsá River has $-35 \%$. Even the magnitudes of the ${ }^{14} \mathrm{C}$ anomalies for the fossil and the modern aquatic mosses are strikingly similar, close to $8 \mathrm{ka}$. 
We conclude that aquatic mosses cannot be used for dating the Markarfljót sediments. As the lowest plant horizons contain only aquatic moss, we are unable to date the lowest part of the sediments. However, we believe the results obtained for terrestrial plants are reliable, i.e., unaffected by the geothermal activity.

\section{REFERENCES}

Andersen, G. J., Heinemeier, J., Nielsen, H. L., Rud, N., Thomsen, M. S., Johnsen, S., Sveinbjörnsdóttir, Á. and Hjartarson, Á. 1989 AMS ${ }^{14} \mathrm{C}$ dating on the Fossvogur sediments, Iceland. In Long, A. and Kra, R. S., eds., Proceedings of the 13 th International ${ }^{14} \mathrm{C}$ Conference. Radiocarbon 31(3): 592-600.

Bruns, M., Levin, I., Münnich, K. O., Hubberten, H. W. and Fillipakis, S. 1980 Regional sources of volcanic carbon dioxide and their influence on ${ }^{14} \mathrm{C}$ content of present-day plant material. In Stuiver, M. and Kra, R. S., eds., Proceedings of the 10th International ${ }^{14} \mathrm{C}$ Conference. Radiocarbon 22(2): 532-536.

Bödvarsson, G. 1961 Physical characteristics of natural heat resources in Iceland. Jökull 11: 29-38.

Chatters, R. M., Crosby, J. W. and Engstrand, L. G. 1969 Fumarole gaseous emanations: their influence on carbon-14 dates. Washington State University College of Engineering Circular 32: $9 \mathrm{p}$.

Einarsson, Th. 1988 Jarðfræði. Saga bergs og lands. Reykjavík, Heimskringla: 335 p (in Icelandic).

Fridleifsson, I. B. 1979 Geothermal activity in Iceland. Jökull 29: 47-56.

Kaldal, I. and Vilmundardóttir, E. 1989 Dating of plant remains in lacustrine sediments in southern Iceland.

In Eiríksson, J. and Geirsdóttir, Á., eds., PhysicsGeophysics-Geology. An Interdisciplinary Field of Research. Nordic Symposium Skálholt, Iceland: 78-79.

Mook, W. G. and van de Plassche, O. 1986 Radiocarbon dating. In van de Plassche, O., ed., Sea-level Research. Norwich, Geo Books: 525-560.

Sæmundsson, K. 1979 Outline of the geology of Iceland. Jökull 29: 7-28.

Saupé, F., Strappa, O., Coppens, R., Guillet, B. and Jaegy, R. 1980 A possible source of error in ${ }^{14} \mathrm{C}$ dates: Volcanic emanations (Examples from the Monte Amiata district, provinces of Grosseto and Sienna, Italy). In Stuiver, M. and Kra, R. S., eds., Proceedings of the 10th International ${ }^{14} \mathrm{C}$ Conference. Radiocarbon 22(2): 525-531.

Vogel, J. S., Southon, J. R., Nelson, D. E. and Brown, T. A. 1984 Performance of catalytically condensed graphite for use in accelerator mass spectrometry. In Wölfli, W., Polach, H. A. and Anderson, H. H., eds., Proceedings of the 3rd International Symposium on Accelerator Mass Spectrometry. Nuclear Instruments and Methods B5: 289-293. 